\title{
Tree species diversity of Pegunungan Bintang, Papua, Indonesia as potency of wood supply
}

\author{
AGUSTINUS MURDJOKO ${ }^{1,2, \vartheta}$, DONY ARISTONE DJITMAU ${ }^{1,2}$, ELIESER VIKTOR SIRAMI ${ }^{1,2}$, \\ RIMA HERLINA SETIAWATI SIBURIAN ${ }^{1}$, ANTONI UNGIRWALU ${ }^{1}$, ZULFIKAR MARDIYADI $^{1}$, \\ JIMMY FRANS WANMA ${ }^{1}$, WOLFRAM YAHYA MOFU ${ }^{1}$, JONNI MARWA ${ }^{1}$, \\ CICILIA MARIA ERNA SUSANTI' ${ }^{1}$, MAX JONDUDAGO TOKEDE ${ }^{1}$, CHRISTIAN SOLEMAN IMBURI ${ }^{1}$, \\ MEKY SAGRIM ${ }^{7}$, HANS MAMBOAI ${ }^{7}$, LUKAS YOWEL SONBAIT ${ }^{8}$, FEBRIZA DWIRANTI, $^{9}$ \\ YENNY YENDRI SALOSA ${ }^{9}$, JOHANA BETY PAEMBONAN ${ }^{3}$, ESTIKO TRI WIRADYO ${ }^{4}$, ERNI UNENOR $^{4}$, \\ NITHANEL MIKAEL HENDRIK BENU ${ }^{5}$, ANDI SASTRA BENNY SARAGIH \\ ${ }^{1}$ Faculty of Forestry, Papua University, Jl. Gunung Salju, Manokwari 98314, West Papua, Indonesia \\ ${ }^{2}$ Research Centre of Biodiversity, Papua University, Jl. Gunung Salju, Manokwari 98314, West Papua, Indonesia. Tel.: +62-986-211430, \\ •email: agustinus.murdjoko.papua@gmail.com \\ ${ }^{3}$ Environment Services, Pegunungan Bintang District, Jl. Kutdol, Oksibil, Pegunungan Bintang 99573, Papua Province, Indonesia \\ ${ }^{4}$ Forestry and Environment Service, Papua Province, Jl. Tanjung Ria, Base G 99771, Jayapura 99117, Papua, Indonesia \\ ${ }^{5}$ Forestry Research and Development Agency of Manokwari. Jl. Inamberi-Susweni, Manokwari 98301, West Papua, Indonesia \\ ${ }^{6}$ Perkumpulan Mnukwar, Jl. Manunggal Besar, Amban, Manokwari 98314, West Papua, Indonesia \\ ${ }^{7}$ Faculty of Agricultural, Papua University, Jl. Gunung Salju, Manokwari 98314, West Papua, Indonesia \\ ${ }^{8}$ Farming Unit, Papua University, Jl. Gunung Salju, Manokwari 98314, West Papua, Indonesia \\ ${ }^{9}$ Faculty of Mathematics and Natural Sciences, Papua University, Jl. Gunung Salju, Manokwari 98314, West Papua, Indonesia
}

Manuscript received: 29 October 2021. Revision accepted: 30 November 2021.

\begin{abstract}
Murdjoko A, Djitmau DA, Sirami EV, Siburian RHS, Ungirwalu A, Mardiyadi Z, Wanma JF, Mofu WY, Marwa J, Susanti CME, Tokede MJ, Imburi CS, Sagrim M, Mamboai H, Sonbait LY, Dwiranti F, Salosa YY, Paembonan JB, Wiradyo ET, Unenor E, Benu NMH, Saragih ASB. 2021. Tree species diversity of Pegunungan Bintang, Papua, Indonesia as potency of wood supply. Biodiversitas 22: 5645-5655. The tropical rainforest is a primary global concern in many aspects. Therefore, this study aimed to describe the tree diversity in Pegunungan Bintang Forest, Papua, Indonesia. There are 10 dominant species from seedlings, saplings, poles, and trees, indicating the timber production potency. This study set systematic plots in Murkim and Teiraplu Sub-districts to collect taxonomic information, diameter, and clear bole height samples. The results showed that the forest was categorized as a tropical mixed due to diverse tree species. The leading plant families included Moraceae, Myrtaceae, Euphorbiaceae, Lauraceae, and Anacardiaceae, with various seedlings, saplings, poles, and trees. The potency of timber was reflected through sample distribution using the reverse J-shaped curve, identifying the merchantable trees with larger and smaller diameters as re-established. However, timber utilization management requires silvicultural treatments using selective logging by diameter limit and logging cycle for forest sustainability.
\end{abstract}

Keywords: New Guinea, Shannon-Wiener index, timber production, understory

\section{INTRODUCTION}

Tropical natural forests as one of the living natural resources still provide benefits and an essential role in life for fulfilling people's lives (Fredericksen and Putz 2003; Uddin et al. 2020; Sonbait et al. 2021). In addition, these forests also provide valuable functions for the sustainability of the ecosystem. For example, the function of forest ecosystems as a water catchment area is to assist in the process of the hydrological cycle so that the availability of water in its sources is correct and it will become a necessity for humans in particular (Lohbeck et al. 2014; Margono et al. 2014). In addition, the function globally is to balance the cycle of nutrients such as carbon, which is currently an international issue where tropical forests are used as carbon sinks and stores. Therefore, the existence of tropical forest ecosystems is essential in their role in social, economic, and ecological life in general (Rozendaal et al. 2019; Murdjoko et al. 2020; Tawer et al. 2021).
Papua (Indonesia) is one of the tropical rain forests, particularly the District of Pegunungan Bintang which consists of the morphology of lakes and rivers (alluvial and colluvial), denuded structural morphology, and glacier morphology. The variation of this area is spread from an altitude of 0 to $4.700 \mathrm{~m}$ above sea level (asl). Pegunungan Bintang District is a segment of Papua's central mountains, an active fold and fault area with a moderate to heavy, undulating topography at an altitude of 1.000-4.700 m asl, and a slope level of $30-45 \%$. There are igneous and igneous rocks metamorphosed in the northern part due to folding and intensive fractures of the Pre-Tertiary and Quaternary age (0.5-2 million years ago). These rocks are characteristic of coal, petroleum, and other metal mineralization potential. The northern mountains of the Pegunungan Bintang District are a reasonably strong collision zone between the oceanic plate and the vast continent (Australia), a mountain (mount) with a slope of $30-45 \%$. This plain consists of sedimentary layers that are part of the 
coastal plains of Papua which indicate the dominance of the floodplain (Murdjoko et al. 2020).

In this tropical forest area in this area, the interaction between humans and forest resources has also occurred for a very long time. These humans have identified and used forest products to fulfill their needs. These forest products have become part of these human activities. This causes these forest products to have economic value in circulation in human activities (Ungirwalu et al. 2014; Ungirwalu et al. 2017). This condition causes the need for forest resources, in this case, timber forest products, to become an established economic mechanism. This condition is currently the reason that this tropical forest area can provide economic functions to humans (Kuswandi and Murdjoko 2015; Murdjoko et al. 2016b). For example, currently, timber forest products are products from tropical forest areas that have been utilized and become part of the economic cycle. The timber forest product is a commodity from trees in the tropical forest (Murdjoko 2013; Kübler et al. 2020). The utilization of these timber forest products has also been going on for a long time and was carried out in official or illegal conditions. Therefore, we hypothesized that the two Sub-districts contained higher diversity of tree species and the individual distribution of tree species over diameter class indicated the stock of tree as timber potency. Therefore, in this study, we aimed to reveal tree diversity in Pegunungan Bintang Forest, Papua, Indonesia as forest description, uncovered species following seedlings, saplings, poles, and trees, and described the potency of timber production. Besides, we provided advice for sustainable forest management during using the tree as a wood supply.

\section{MATERIALS AND METHODS}

\section{Study area}

The study was conducted in Murkim and Teiraplu Subdistricts in Pegunungan Bintang District, Papua Province, Indonesia. The Murkim Sub-district is located in the

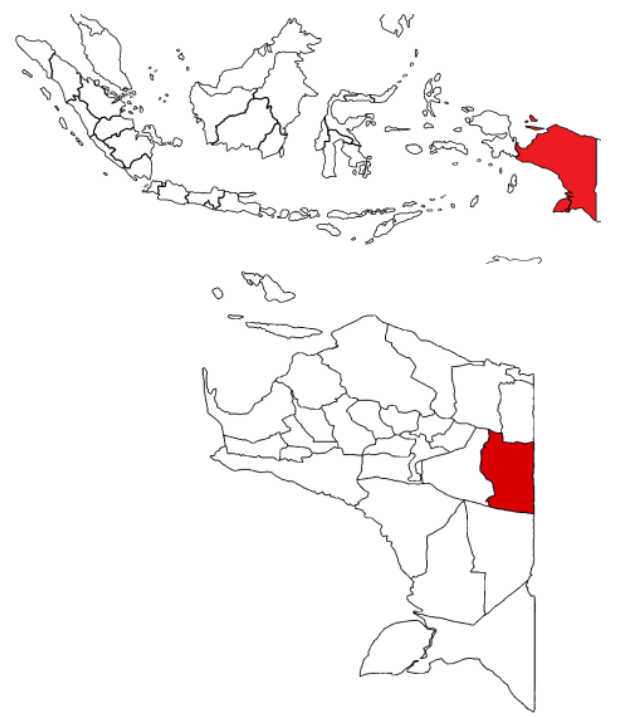

eastern part covering $359 \mathrm{~km}^{2}$ as per the administrative boundaries. It is located at coordinates $140^{\circ} 39^{\prime} 35,289^{\prime \prime}-$ $41^{\circ} 00^{\prime} 00,00^{\prime \prime} \mathrm{E}$ and $04^{\circ} 00^{\prime} 59,196^{\prime \prime}-04^{\circ} 21^{\prime} 54.82^{\prime \prime} \mathrm{S}$ (Figure 1). In contrast, the Teiraplu Sub-district is located in the north, spread at $1,469 \mathrm{~km}^{2}$. It is located at coordinates $140^{\circ} 13^{\prime} 26,618^{\prime \prime}-140^{\circ} 30^{\prime} 47,699^{\prime \prime} \mathrm{E}$ and $03^{\circ} 44^{\prime} 42,041^{\prime \prime}-$ $04^{\circ} 26^{\prime 23,674 " ~ S . ~ T h e ~ P e g u n u n g a n ~ B i n t a n g ~ D i s t r i c t ~ i s ~}$ located in Papua Province, Indonesia, directly bordering Papua New Guinea (PNG). It covers 1,586,300 hectares and is dominated by mountainous areas $(66.09 \%)$ and hilly areas $(27.26 \%)$. Its area is approximately $\pm 4.01 \%$ of Papua Province, with a flat distance of $111 \mathrm{~km}$ from West to East and $160 \mathrm{~km}$ from North to South (Kartikasari et al. 2012; Murdjoko et al. 2020).

\section{Samplings and survey}

We applied the systematic plots during data collection where the 24 plots were placed in each Sub-district, Teiraplu, and Murkim, respectively. The distance among the plot was more or less $100 \mathrm{~m}$. Then, the plot size was 20 $\mathrm{m} \times 20 \mathrm{~m}$ for tree and 3 subplots (10 m x $10 \mathrm{~m}$ for pole, 5 $\mathrm{m} \times 5 \mathrm{~m}$ for sapling, and $2 \mathrm{~m} \times 2 \mathrm{~m}$ for seedling). Data were the number of individuals in the plot, species of tree, pole, sapling, and seedling for taxonomic information. Species were recognized to species level by means of morphological characters based on determinant keys and unidentified species were sent as voucher to the Herbarium Papuaense of Balai Penelitian dan Pengembangan Lingkungan Hidup dan Kehutanan (BP2LHK) Manokwari and Herbarium Manokwariense (MAN) Pusat Penelitian Keanekaragaman Hayati Universitas Papua (PPKHUNIPA), Manokwari. The scientific name of the species was based on World Flora Online (WFO) at the website: http://www.worldfloraonline.org/. Then, diameter and clear bole height was measured for tree pole and tree using phi band and Haga hypsometer, respectively. The diameter was measured at $1.3 \mathrm{~m}$ from the ground or at breast height and more or less 10 above the buttress. The clear bole height was measured at the vantage point below the first branch.

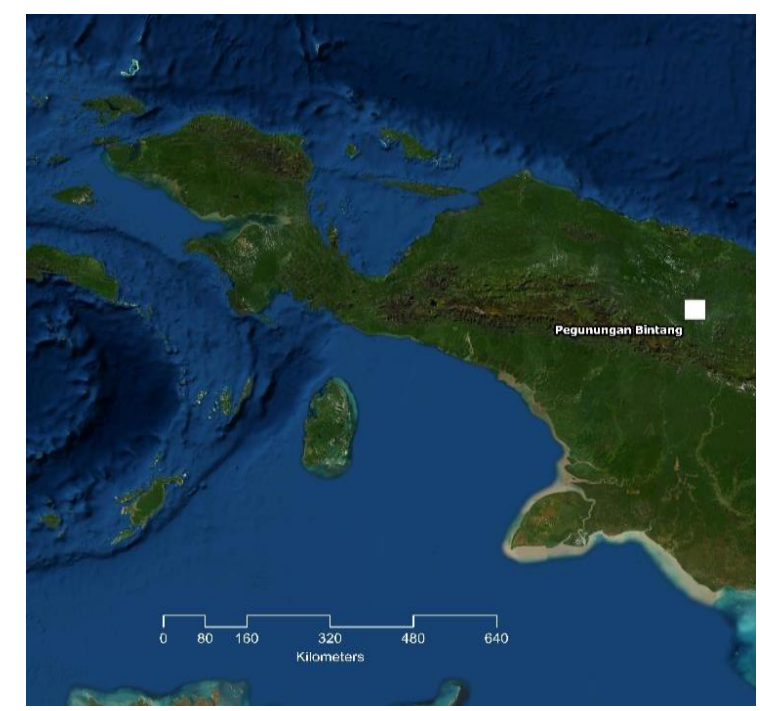

Figure 1. Location of research in Pegunungan Bintang Forest, Papua, Indonesia (symbolized by white box) 


\section{Data analysis}

We calculated the diversity and evenness of species in both Sub-districts using the Shannon-Wiener index and Pielou's evenness, respectively, computed as:

$$
\mathrm{H}^{\prime}=-\sum_{\mathrm{i}=1}^{S} \mathrm{p}_{\mathrm{i}} \ln \left(\mathrm{p}_{\mathrm{i}}\right)
$$

Where:

$H^{\prime}$ is Shannon-Wiener index

$p_{1}$ is the number of samples where species $i$ is present

Pielou's evenness was computed using:

$$
\mathrm{J}=\mathrm{H}^{\prime} /[\ln (\mathrm{S})]
$$

Where: $\mathrm{S}$ is the total number of species for each type of forest (Spellerberg and Fedor 2003; Tawer et al. 2021).

Moreover, we also computed the Importance Value Index (IVI) of species by adding relative frequency, density, and dominance as:

$$
\begin{aligned}
& \mathrm{IVI}_{\mathrm{i}}=\mathrm{RFr}_{\mathrm{i}}+\mathrm{RDe}_{\mathrm{i}}+\mathrm{RDo_{i }} \text { (for pole and tree) } \\
& \mathrm{IVI}_{\mathrm{i}}=\mathrm{RFr}_{\mathrm{i}}+\mathrm{RDe}_{\mathrm{i}} \text { (for sapling and seedling) }
\end{aligned}
$$

Where: $\mathrm{IVI}_{\mathrm{i}}$ is the important value index of species $i$, $\mathrm{RFr}_{\mathrm{i}}$ is the relative frequency of species $i, \mathrm{RDe}_{\mathrm{i}}$ is the relative density of species $i$, and $\mathrm{RDo}_{\mathrm{i}}$ is the relative dominance of species $i$ (Cottam and Curtis 1956; Murdjoko et al. 2016a; Fatem et al. 2020).

\section{RESULTS AND DISCUSSION}

\section{Forest description}

The two Sub-districts consist of natural tropical forests with high species diversity. The results showed 56 tree families with 185 species (Table 2). It indicated that the tree species diversity was high because this area was part of New Guinea harboring plenty of species vegetation
(Whitfeld et al. 2014; Cámara-Leret et al. 2020; Murdjoko et al. 2020). The identified trees were categorized into four phases: seedlings, saplings, poles, and trees. Additionally, other vegetation was identified as the primary category of tropical forests characteristics. However, this study's main objective was the tree species.

The forests are diverse with similar tree species, indicated by an almost similar Shannon-Wiener diversity index $\left(\mathrm{H}^{\prime}\right)$ at 2.758 for Murkim Sub-district and 2.765 for Teiraplu. The tree species evenness value distribution was 0.930 and 0.937 for Murkim and Teiraplu Sub-districts, respectively (Table 1). Therefore, the diversity and tree species are evenly distributed, and none dominates both forests (Spellerberg and Fedor 2003).

Besides, the distribution of taxon for family levels in the forest in the two sub-districts cannot be dominated by particular families. This condition indicates that the forest formed in these two sub-districts is a tropical mixed forest. However, it can be analyzed to show the position of the taxon at the family level in this forest based on the number of species and individuals so that many family levels in this forest can be sorted. From the analysis results, the families occupying the top five positions were Moraceae, Myrtaceae, Euphorbiaceae, Lauraceae, and Anacardiaceae (Figure 2). Furthermore, the five families have the most significant proportion with more than three percent, while the other 76 families have the same value with the highest distribution being three percent. Thus, the forests in these two sub-districts form a mixed tropical forest where this forest forms its ecosystem by interacting between species in several lifeforms that are present together with trees (Murdjoko et al. 2016a; Murdjoko et al. 2020).

Table 1. Diversity and evenness scores in the two sub-districts where $\mathrm{H}$ 'is Shannon diversity index and $\mathrm{J}$ is Evenness

\begin{tabular}{lcccccc}
\hline Location & \multicolumn{2}{c}{ Murkim } & \multicolumn{2}{c}{ Teiraplu } & \multicolumn{2}{c}{ Both sub-district } \\
\hline Index & $\mathrm{H}^{\prime}$ & $\mathrm{J}$ & $\mathrm{H}^{\prime}$ & $\mathrm{J}$ & $\mathrm{H}^{\prime}$ & $\mathrm{J}$ \\
Mean & 2.758 & 0.930 & 2.765 & 0.937 & 3.320 & 0.938 \\
Standard & 0.495 & 0.051 & 0.245 & 0.036 & 0.518 & 0.027 \\
deviation & & & & & & \\
\hline
\end{tabular}

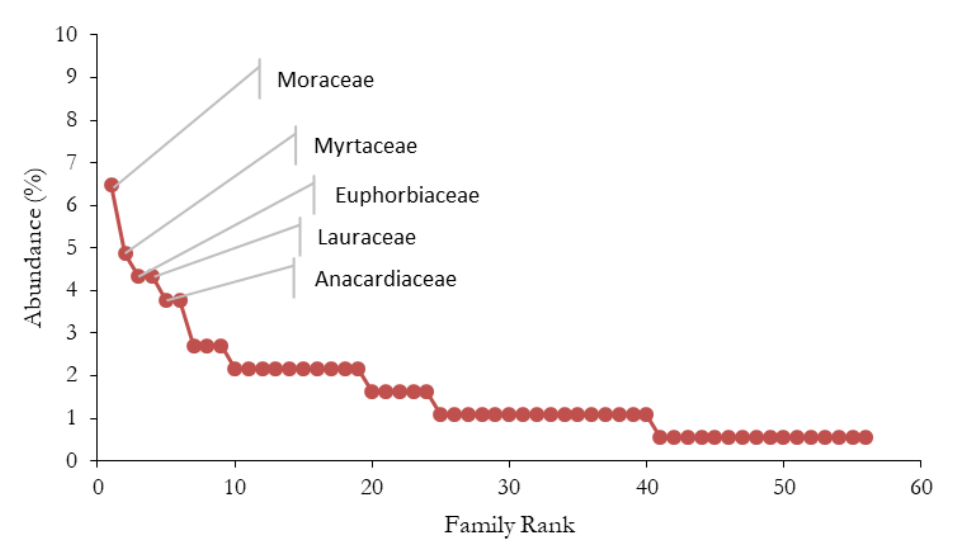

Figure 2. Taxon sequences for Family Rank (x-axis) based on the proportion of the number of species and individuals as a percentage (y-axis) in the two sub-districts 
Table 2. List of tree species in two sub-districts and the" $\sqrt{ }$ " is the symbol of the presence of tree species

Tree species $\frac{\begin{array}{c}\text { Sub- } \\ \text { district }\end{array}}{$\cline { 2 - 3 }}

Acronychia brassii T.G.Hartley

Acronychia reticulata Lauterb.

Acronychia sp.

Actinodaphne nitida Teschner

Adinandra integerrima T.Anderson ex Dyer

Aglaia argentea Blume

Aglaia spectabilis (Miq.) S.S.Jain \& S.Bennet

Alphitonia incana (Roxb.) Teijsm. \& Binn. ex Kurz

Alstonia scholaris (L.) R. Br.

Alstonia spectabilis $\mathrm{R} . \mathrm{Br}$.

Antiaris toxicaria Lesch.

Antiaropsis decipiens K.Schum.

Archidendron parviflorum Pulle

Artocarpus altilis (Parkinson ex F.A.Zorn) Fosberg

Beilschmiedia morobensis Kosterm.

Bischofia javanica Blume

Blumeodendron tokbrai (Blume) Kurz

Buchanania arborescens (Blume) Blume

Buchanania macrocarpa Lauterb.

Callicarpa longifolia Lam.

Calophyllum caudatum Kaneh. \& Hatus.

Calophyllum inophyllum $\mathrm{L}$.

Campnosperma brevipetiolatum Volkens

Cananga odorata (Lam.) Hook.f. \& Thomson

Canarium asperum Benth.

Canarium hirsutum Willd.

Canarium indicum $\mathrm{L}$.

Canarium rigidum (Blume) Zipp. ex Miq.

Carallia brachiata (Lour.) Merr.

Casearia carrii Sleumer

Casearia monticola Sleumer

Casearia sp.

Casearia urophylla Gilg

Cerbera floribunda K.Schum.

Chionanthus macrocarpus Blume

Chisocheton ceramicus Miq.

Chrysophyllum papuanicum (Pierre ex Dubard)

Royen

Cleistanthus papuanus (Lauterb.) Jabl.

Cochlospermum gillivraei Benth.

Commersonia bartramia (L.) Merr.

Corynocarpus laevigatus J.R.Forst. \& G.Forst.

Cryptocarya palmerensis C.K.Allen

Cryptocarya sp.

Decaspermum parviflorum (Lam.) A.J.Scott

Dillenia papuana Martelli

Diospyros papuana Valeton ex Bakh.

Diospyros pilosanthera Blanco

Diospyros sp.

Dracontomelon dao (Blanco) Merr. \& Rolfe

Drypetes globosa (Merr.) Pax \& K.Hoffm.

Dysoxylum mollissimum Blume

Elaeocarpus angustifolius Blume

Elaeocarpus arnhemicus F.Muell.

Endiandra rubescens (Blume) Miq.

Endiandra virens F.Muell.

Endospermum medullosum L.S.Sm.
Eucalyptopsis papuana C.T.White

Fagraea elliptica Roxb.

Fagraea racemosa Jack

Ficus annulata Blume

Ficus chrysolepis Miq.

Ficus hispida L.f.

Ficus nodosa Teijsm. \& Binn.

Ficus racemosa $\mathrm{L}$.

Ficus robusta Corner

Ficus septica Burm.f.

Ficus sp.

Ficus sycomorus $\mathrm{L}$.

Ficus variegata Blume

Flindersia pimenteliana F.Muell.

Galbulimima belgraveana (F.Muell.) Sprague

Garcinia latissima Miq.

Garcinia picrorhiza Miq.

Garcinia sp.

Gironniera nervosa Planch.

Glochidion sp.

Gmelina sessilis C.T.White \& W.D.Francis ex Lane-Poole

Gnetum gnemon L.

Goniothalamus giganteus Hook.f. \& Thomson

Gonocaryum litorale (Blume) Sleumer

Grewia eriocarpa Juss.

Gymnacranthera farquhariana (Hook.f. \& Thomson) Warb.

Halfordia kendack Guillaumin

Haplolobus celebicus H.J.Lam

Haplolobus floribundus (K.Schum.) H.J.Lam

Haplolobus lanceolatus H.J.Lam ex Leenh.

Harpullia carrii Leenh.

Heritiera sylvatica S.Vidal

Homalanthus novoguineensis (Warb.) K.Schum.

Homalanthus populneus (Geiseler) Pax

Homalium foetidum Benth.

Hopea celtidifolia Kosterm.

Hopea novoguineensis Slooten

Hopea papuana Diels

Horsfieldia irya (Gaertn.) Warb.

Horsfieldia laevigata Warb.

Horsfieldia parviflora (Roxb.) J.Sinclair

Horsfieldia sylvestris Warb.

Intsia palembanica Miq.

Jagera pseudorhus Radlk.

Kibara bullata Philipson

Kibara coriacea (Blume) Hook. f. \& A. Thomps.

Kibara elongata A.C.Sm.

Kleinhovia hospita L.

Knema intermedia Warb.

Lithocarpus rufovillosus (Markgr.) Rehder

Litsea firma (Blume) Hook.f.

Litsea ledermannii Teschner

Litsea sp.

Litsea timoriana Span.

Maasia glauca (Hassk.) Mols, Kessler \& Rogstad

Maasia sumatrana (Miq.) Mols, Kessler \& Rogstad

Macaranga densiflora Warb.

Macaranga gigantea (Rchb.f. \& Zoll.) Müll.Arg.

Macaranga mappa (L.) Müll.Arg.

Macaranga tanarius (L.) Müll.Arg.

Magnolia tsiampacca (L.) Figlar \& Noot.

Mallotus philippensis (Lam.) Müll.Arg.

Mallotus sp.

Maniltoa browneoides Harms

Maniltoa plurijuga Merr. \& L.M.Perry

Mastixiodendron pachyclados (K.Schum.) Melch.

Medusanthera laxiflora (Miers) R.A.Howard

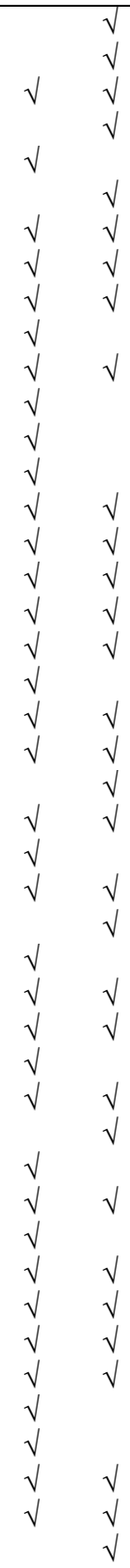

$\sqrt{ }$ 


\begin{tabular}{|c|c|c|}
\hline Melicope bonwickii (F. Muell.) T.G. Hartley & $\sqrt{ }$ & \\
\hline Melicope elleryana (F. Muell.) T.G. Hartley & $\sqrt{ }$ & $\sqrt{ }$ \\
\hline Myristica ensifolia J.Sinclair & & $\sqrt{ }$ \\
\hline Myristica fatua Houtt. & $\sqrt{ }$ & $\sqrt{ }$ \\
\hline Myristica gigantea King & $\sqrt{ }$ & $\sqrt{ }$ \\
\hline Myristica globosa Warb. & $\sqrt{ }$ & \\
\hline Myristica hollrungii Warb. & & $\sqrt{ }$ \\
\hline Nauclea orientalis (L.) L. & & $\sqrt{ }$ \\
\hline Neolamarckia cadamba (Roxb.) Bosser & $\sqrt{ }$ & $\sqrt{ }$ \\
\hline Ochrosia glomerata (Blume) F.Muell. & $\sqrt{ }$ & \\
\hline Octamyrtus insignis Diels & & $\sqrt{ }$ \\
\hline Palaquium lobbianum Burck & $\sqrt{ }$ & $\sqrt{ }$ \\
\hline Pararchidendron pruinosum (Benth.) I.C.Nielsen & & $\sqrt{ }$ \\
\hline Parastemon versteeghii Merr. \& L.M.Perry & $\sqrt{ }$ & $\sqrt{ }$ \\
\hline Phaleria macrocarpa (Scheff.) Boerl. & $\sqrt{ }$ & \\
\hline Picrasma javanica Blume & $\sqrt{ }$ & \\
\hline Pimelodendron amboinicum Hassk. & $\sqrt{ }$ & $\sqrt{ }$ \\
\hline Pisonia longirostris Teijsm. \& Binn. & $\sqrt{ }$ & $\sqrt{ }$ \\
\hline Planchonella anteridifera (C.T.White \& & & $\sqrt{ }$ \\
\hline W.D.Francis ex Lane-Poole) H.J.Lam & & \\
\hline Planchonella keyensis H.J.Lam & $\sqrt{ }$ & $\sqrt{ }$ \\
\hline Polyscias nodosa (Blume) Seem. & $\sqrt{ }$ & $\sqrt{ }$ \\
\hline Pometia acuminata Radlk. & $\sqrt{ }$ & $\sqrt{ }$ \\
\hline Pometia pinnata J.R.Forst. \& G.Forst. & $\sqrt{ }$ & $\sqrt{ }$ \\
\hline Premna corymbosa Rottler \& Willd. & $\sqrt{ }$ & \\
\hline Prunus arborea (Blume) Kalkman & $\sqrt{ }$ & $\sqrt{ }$ \\
\hline Prunus javanica (Teijsm. \& Binn.) Miq. & $\sqrt{ }$ & $\sqrt{ }$ \\
\hline Pterocarpus indicus Willd. & $\sqrt{ }$ & $\sqrt{ }$ \\
\hline Pterocymbium beccarii K.Schum. & $\sqrt{ }$ & \\
\hline Rapanea tempanpan P.Royen & & $\sqrt{ }$ \\
\hline Rhodamnia cinerea Jack & $\sqrt{ }$ & $\sqrt{ }$ \\
\hline Rhus lamprocarpa Merr. \& L.M.Perry & & $\sqrt{ }$ \\
\hline Rhus taitensis Guill. & $\sqrt{ }$ & $\sqrt{ }$ \\
\hline
\end{tabular}

With the high diversity of taxon species, the condition of this mixed natural forest can be analyzed to show several species that grow and dominate at the seedling, sapling, poles, and tree levels in each sub-district. The analysis used is to use the IVI in percentage, as shown in Table 3. At each level, it can be seen that the species present in the top ten positions differ. This indicates that the dynamic conditions of stand composition in this forest vary widely. The position of adult individuals, in this case, is the level of poles and trees, has a regeneration process that depends on the state of the forest, such as competition between species, so that many species at the seedling and sapling levels as a reflection of the regeneration of the adult individual are controlled by other species. For example, in Teraplu Subdistrict, at the adult level, it is Melicope elleryana ( $\mathrm{F}$. Muell.) T.G. Hartley, Pararchidendron pruinosum (Benth.) I.C.Nielsen, Parastemon versteeghii Merr. \& L.M.Perry and Vatica rassak Blume.

However, there are many different species at the seedling and sapling levels, namely Xanthostemon novaguineensis Valeton, Gymnacranthera farquhariana (Hook.f \& Thomson) Warb., Macaranga densilora Warb. and Aglaia argentea Blume. This phenomenon is normal in tropical forests where adult species that dominate a certain area do not necessarily have good regeneration abilities. This is due to elusive factors in mixed tropical forest ecosystems. However, this situation can be presumed due to heterospecific and conspecific associations that occur as

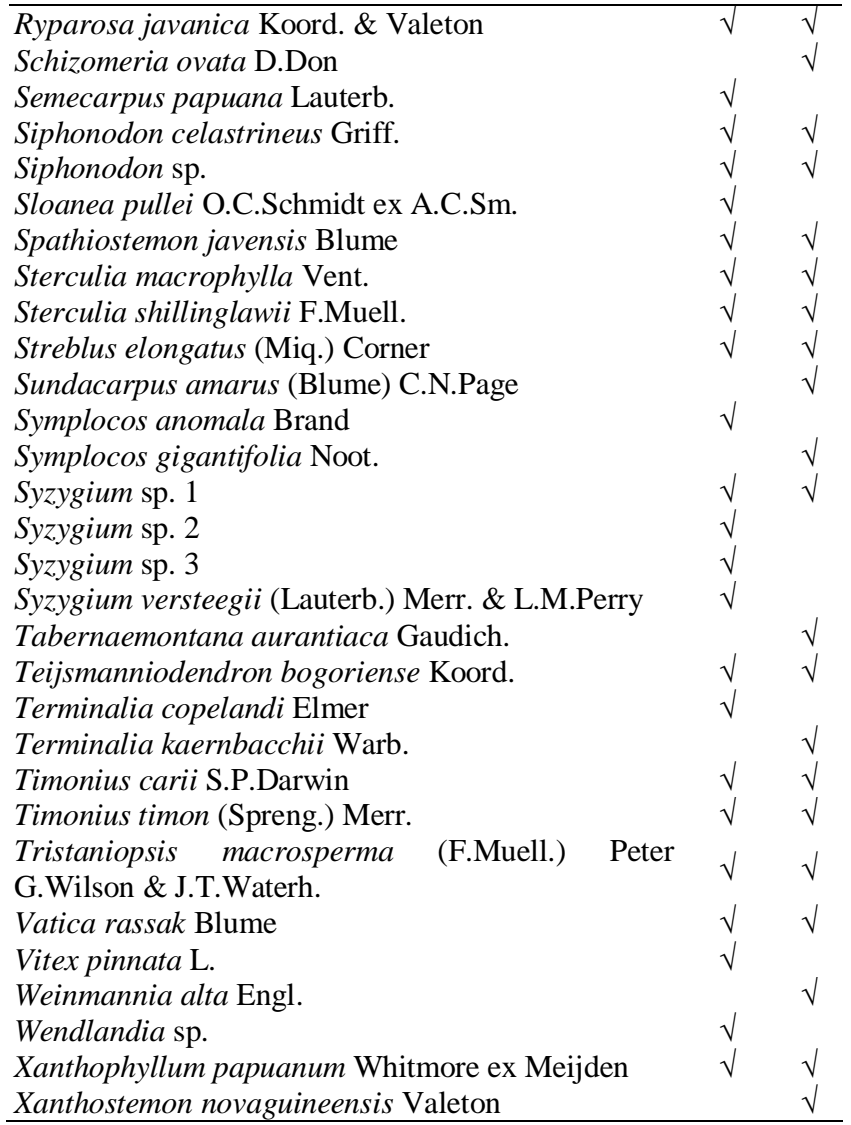

a relationship between the same individuals in one species or different species (Murdjoko et al. 2016c; Murdjoko et al. 2017; Murdjoko et al. 2020). This kind of situation needs to be a concern in tropical forest management, especially for the problem of regeneration that occurs, so it is necessary not to intervene to support the regeneration process of species in this forest (Menezes et al. 2019; Mahayani et al. 2020).

\section{Potential of timber products}

From the conditions of this mixed tropical forest, tree species can be described to benefit potential timber forest products which can be seen from the indicators of the number of individuals and the volume per unit area of a hectare (de Avila et al. 2017). Therefore, the grouping of the potential distribution is based on the diameter class group with an interval of $10 \mathrm{~cm}$ (Figures 3 and 4). According to the Regulation of the Minister of Environment and Forestry of the Republic of Indonesia Number: P.42 / Menlhk-Setjen / 2015 concerning Administration of Timber Forest Products Originating from Natural Forests, timber forest products consist of three, namely large logs (KBB), medium logs (KBS) and small $\log _{s}(\mathrm{KBK})$. Therefore, the distribution of diameter classes for these two sub-districts is about $80 \mathrm{~cm}$ high and based on this regulation, forest areas in these two sub-districts can produce timber forest products in the form of KBK, KBS, and KBB. 
Table 3. Ten leading species for seedlings, saplings, poles, and trees in each sub-district were dominant based on the Importance Value Index (IVI)

\begin{tabular}{|c|c|c|c|c|c|c|c|}
\hline Species & $\mathbf{F}$ & D & Do & $\mathbf{R F}$ & RD & RDo & IVI $(\%)$ \\
\hline \multicolumn{8}{|l|}{ Sub-district Teiraplu } \\
\hline \multicolumn{8}{|l|}{ Seedlings } \\
\hline Xanthostemon novaguineensis & 0.17 & 0.92 & n.a & 2.90 & 8.56 & n.a & 11.46 \\
\hline Gymnacranthera farquhariana & 0.29 & 0.58 & n.a & 5.07 & 5.45 & n.a & 10.52 \\
\hline Fagraea racemosa & 0.25 & 0.38 & n.a & 4.35 & 3.50 & n.a & 7.85 \\
\hline Aglaia argentea & 0.17 & 0.46 & n.a & 2.90 & 4.28 & n.a & 7.18 \\
\hline Geniostoma rupestre & 0.17 & 0.46 & n.a & 2.90 & 4.28 & n.a & 7.18 \\
\hline Canarium hirsutum & 0.13 & 0.50 & n.a & 2.17 & 4.67 & n.a & 6.84 \\
\hline Garcinia latissima & 0.17 & 0.33 & n.a & 2.90 & 3.11 & n.a & 6.01 \\
\hline Gnetum gnemon & 0.21 & 0.25 & n.a & 3.62 & 2.33 & n.a & 5.96 \\
\hline Vatica rassak & 0.21 & 0.21 & n.a & 3.62 & 1.95 & n.a & 5.57 \\
\hline Canarium indicum & 0.17 & 0.25 & n.a & 2.90 & 2.33 & n.a & 5.23 \\
\hline \multicolumn{8}{|l|}{ Saplings } \\
\hline Macaranga densiflora & 0.42 & 0.88 & n.a & 4.39 & 5.87 & n.a & 10.25 \\
\hline Aglaia argentea & 0.42 & 0.83 & n.a & 4.39 & 5.59 & n.a & 9.97 \\
\hline Fagraea racemosa & 0.33 & 0.67 & n.a & 3.51 & 4.47 & n.a & 7.98 \\
\hline Teijsmanniodendron bogoriense & 0.33 & 0.67 & n.a & 3.51 & 4.47 & n.a & 7.98 \\
\hline Vatica rassak & 0.25 & 0.54 & n.a & 2.63 & 3.63 & n.a & 6.26 \\
\hline Pararchidendron pruinosum & 0.25 & 0.33 & n.a & 2.63 & 2.23 & n.a & 4.87 \\
\hline Canarium indicum & 0.21 & 0.38 & n.a & 2.19 & 2.51 & n.a & 4.71 \\
\hline Gmelina sessilis & 0.21 & 0.29 & n.a & 2.19 & 1.96 & n.a & 4.15 \\
\hline Prunus arborea & 0.21 & 0.29 & n.a & 2.19 & 1.96 & n.a & 4.15 \\
\hline Canarium hirsutum & 0.21 & 0.25 & n.a & 2.19 & 1.68 & n.a & 3.87 \\
\hline \multicolumn{8}{|l|}{ Poles } \\
\hline Melicope elleryana & 0.13 & 0.25 & 0.00 & 3.70 & 6.38 & 7.30 & 17.38 \\
\hline Pararchidendron pruinosum & 0.17 & 0.25 & 0.00 & 4.94 & 6.38 & 4.78 & 16.10 \\
\hline Acronychia reticulata & 0.17 & 0.21 & 0.00 & 4.94 & 5.32 & 3.57 & 13.82 \\
\hline Lithocarpus rufovillosus & 0.13 & 0.17 & 0.00 & 3.70 & 4.26 & 5.36 & 13.32 \\
\hline Parastemon versteeghii & 0.17 & 0.17 & 0.00 & 4.94 & 4.26 & 4.07 & 13.26 \\
\hline Vatica rassak & 0.17 & 0.17 & 0.00 & 4.94 & 4.26 & 3.74 & 12.93 \\
\hline Xanthostemon novaguineensis & 0.08 & 0.17 & 0.00 & 2.47 & 4.26 & 4.85 & 11.57 \\
\hline Pometia pinnata & 0.08 & 0.13 & 0.00 & 2.47 & 3.19 & 4.54 & 10.20 \\
\hline Homalanthus novoguineensis & 0.08 & 0.17 & 0.00 & 2.47 & 4.26 & 3.02 & 9.75 \\
\hline Prunus arborea & 0.13 & 0.13 & 0.00 & 3.70 & 3.19 & 2.39 & 9.28 \\
\hline \multicolumn{8}{|l|}{ Trees } \\
\hline Parastemon versteeghii & 0.46 & 0.58 & 0.07 & 11.00 & 12.96 & 17.78 & 41.74 \\
\hline Vatica rassak & 0.25 & 0.33 & 0.02 & 6.00 & 7.41 & 5.27 & 18.67 \\
\hline Lithocarpus rufovillosus & 0.29 & 0.29 & 0.02 & 7.00 & 6.48 & 4.31 & 17.80 \\
\hline Xanthostemon novaguineensis & 0.21 & 0.21 & 0.03 & 5.00 & 4.63 & 6.93 & 16.56 \\
\hline Gironniera nervosa & 0.25 & 0.25 & 0.01 & 6.00 & 5.56 & 3.65 & 15.20 \\
\hline Intsia palembanica & 0.08 & 0.08 & 0.02 & 2.00 & 1.85 & 4.82 & 8.67 \\
\hline Decaspermum parviflorum & 0.13 & 0.13 & 0.01 & 3.00 & 2.78 & 2.33 & 8.11 \\
\hline Teijsmanniodendron bogoriense & 0.13 & 0.13 & 0.01 & 3.00 & 2.78 & 2.27 & 8.05 \\
\hline Eucalyptopsis papuana & 0.04 & 0.04 & 0.02 & 1.00 & 0.93 & 5.66 & 7.59 \\
\hline Litsea timoriana & 0.13 & 0.13 & 0.01 & 3.00 & 2.78 & 1.81 & 7.58 \\
\hline \multicolumn{8}{|l|}{ Sub-district Murkim } \\
\hline \multicolumn{8}{|l|}{ Seedlings } \\
\hline Hopea novoguineensis & 0.44 & 2.64 & n.a & 7.38 & 22.37 & n.a & 29.76 \\
\hline Canarium indicum & 0.40 & 0.84 & n.a & 6.71 & 7.12 & n.a & 13.83 \\
\hline Premna corymbosa & 0.24 & 0.60 & n.a & 4.03 & 5.08 & n.a & 9.11 \\
\hline Lithocarpus rufovillosus & 0.20 & 0.48 & n.a & 3.36 & 4.07 & n.a & 7.42 \\
\hline Ficus robusta & 0.20 & 0.44 & n.a & 3.36 & 3.73 & n.a & 7.08 \\
\hline Glochidion sp. & 0.16 & 0.36 & n.a & 2.68 & 3.05 & n.a & 5.74 \\
\hline Sloanea pullei & 0.20 & 0.28 & n.a & 3.36 & 2.37 & n.a & 5.73 \\
\hline Fagraea racemosa & 0.16 & 0.20 & n.a & 2.68 & 1.69 & n.a & 4.38 \\
\hline Maniltoa browneoides & 0.16 & 0.20 & n.a & 2.68 & 1.69 & n.a & 4.38 \\
\hline Chrysophyllum papuanicum & 0.04 & 0.36 & n.a & 0.67 & 3.05 & n.a & 3.72 \\
\hline
\end{tabular}




\begin{tabular}{|c|c|c|c|c|c|c|c|}
\hline \multicolumn{8}{|l|}{ Saplings } \\
\hline Ficus sp. & 0.52 & 1.28 & n.a & 4.63 & 7.60 & n.a & 12.23 \\
\hline Macaranga densiflora & 0.40 & 0.84 & n.a & 3.56 & 4.99 & n.a & 8.55 \\
\hline Premna corymbosa & 0.40 & 0.84 & n.a & 3.56 & 4.99 & n.a & 8.55 \\
\hline Ficus robusta & 0.36 & 0.60 & n.a & 3.20 & 3.56 & n.a & 6.77 \\
\hline Syzygium sp. 1 & 0.36 & 0.48 & n.a & 3.20 & 2.85 & n.a & 6.05 \\
\hline Hopea novoguineensis & 0.24 & 0.60 & n.a & 2.14 & 3.56 & n.a & 5.70 \\
\hline Ficus sycomorus & 0.24 & 0.44 & n.a & 2.14 & 2.61 & n.a & 4.75 \\
\hline Callicarpa longifolia & 0.24 & 0.40 & n.a & 2.14 & 2.38 & n.a & 4.51 \\
\hline Canarium indicum & 0.24 & 0.36 & n.a & 2.14 & 2.14 & n.a & 4.27 \\
\hline Intsia palembanica & 0.24 & 0.36 & n.a & 2.14 & 2.14 & n.a & 4.27 \\
\hline \multicolumn{8}{|l|}{ Poles } \\
\hline Syzygium sp. 1 & 0.24 & 0.36 & 0.01 & 7.14 & 9.09 & 9.03 & 25.27 \\
\hline Hopea novoguineensis & 0.20 & 0.24 & 0.00 & 5.95 & 6.06 & 6.61 & 18.62 \\
\hline Alphitonia incana & 0.08 & 0.28 & 0.01 & 2.38 & 7.07 & 8.58 & 18.03 \\
\hline Ficus sp. & 0.16 & 0.20 & 0.00 & 4.76 & 5.05 & 5.61 & 15.42 \\
\hline Intsia palembanica & 0.16 & 0.16 & 0.00 & 4.76 & 4.04 & 3.71 & 12.51 \\
\hline Gymnacranthera farquhariana & 0.12 & 0.12 & 0.00 & 3.57 & 3.03 & 3.16 & 9.76 \\
\hline Hopea papuana & 0.08 & 0.12 & 0.00 & 2.38 & 3.03 & 3.43 & 8.85 \\
\hline Pometia acuminata. & 0.08 & 0.12 & 0.00 & 2.38 & 3.03 & 3.20 & 8.61 \\
\hline Canarium hirsutum & 0.08 & 0.08 & 0.00 & 2.38 & 2.02 & 3.15 & 7.55 \\
\hline Parastemon versteeghii & 0.08 & 0.12 & 0.00 & 2.38 & 3.03 & 2.11 & 7.52 \\
\hline \multicolumn{8}{|l|}{ Trees } \\
\hline Intsia palembanica & 0.24 & 0.28 & 0.09 & 6.82 & 7.45 & 25.98 & 40.24 \\
\hline Hopea novoguineensis & 0.44 & 0.48 & 0.05 & 12.50 & 12.77 & 13.06 & 38.33 \\
\hline Lithocarpus rufovillosus & 0.16 & 0.20 & 0.02 & 4.55 & 5.32 & 4.56 & 14.43 \\
\hline Buchanania arborescens & 0.16 & 0.16 & 0.01 & 4.55 & 4.26 & 3.88 & 12.68 \\
\hline Knema intermedia & 0.16 & 0.16 & 0.01 & 4.55 & 4.26 & 2.71 & 11.51 \\
\hline Vatica rassak & 0.12 & 0.16 & 0.01 & 3.41 & 4.26 & 2.09 & 9.76 \\
\hline Palaquium lobbianum & 0.12 & 0.12 & 0.01 & 3.41 & 3.19 & 2.40 & 9.00 \\
\hline Hopea papuапа & 0.08 & 0.08 & 0.01 & 2.27 & 2.13 & 2.60 & 7.00 \\
\hline Tristaniopsis macrosperma & 0.08 & 0.08 & 0.01 & 2.27 & 2.13 & 2.37 & 6.77 \\
\hline Campnosperma brevipetiolatum & 0.08 & 0.08 & 0.01 & 2.27 & 2.13 & 2.11 & 6.51 \\
\hline
\end{tabular}

Note: F is the frequency, D is the density, Do is the dominance, RF is the Relative Frequency, RD is the Relative Density, RDo is the Relative Dominance and the IVI (\%) is the Importance Value Index, n.a. is not applicable

Therefore, in presenting this data, it is divided into groups of diameter classes so that the potential for this forest product is included and can be managed according to the type of wood to be produced. In these two sub-districts, the number of individuals in the diameter class below 10 $\mathrm{cm}$ is the highest and decreases with the increasing diameter class (Figure 3). However, the potential for timber forest products is found in diameter classes above $10 \mathrm{~cm}$ where these forest products can be used or utilized. In addition, the economic value of the potential of these forest products can be measured in quantity and later by volume (Groenendijk et al. 2017).

From the calculation of the potential for timber forest products according to volume per unit area in hectares and diameter class $(\mathrm{cm})$, it can be seen that the highest volume is in the $10-19 \mathrm{~cm}$ diameter class around $100 \mathrm{~m}^{3} . \mathrm{ha}^{-1}$ then tends to decrease. The increase in diameter except in diameter class 50-59 cm (Figure 4). This situation shows that the potential of timber forest products in these two subdistricts is still complete, where small to large diameters are still formed in this mixed natural forest structure. The reverse J-shaped curve in the graphs indicated that the forest had a more or less good condition (Myanmar 2016; Padmakumar et al. 2018). Based on the distribution of the number of individuals per unit area of a hectare and diameter class for the two sub-districts, it can be seen that the number of individuals scattered in the two sub-districts did not experience a big difference (Figure 5). The distribution of the number of individuals is still complete for each diameter class. This distribution pattern shows a decrease and an increase in the diameter class. The distribution of potential timber forest products in the two sub-districts does not indicate a big difference. This can be seen from the shape of the distribution that is almost the same in the two sub-districts. Only me in the $50-59 \mathrm{~cm}$ diameter class, there are no individuals in Teiraplu Subdistrict. Conclusively, the potential for timber forest products in the two sub-districts spreads from the smalldiameter class to the largest diameter class, namely 80-89 $\mathrm{cm}$ (Figure 6).

A correlation relationship can be made between the two conditions based on the distribution pattern of potential timber forest products measured in units of volume $\left(\mathrm{m}^{3}\right)$ per tree and diameter $(\mathrm{cm})$. The result of regression analysis produces a mathematical equation is $\mathrm{y}=$ $0.0002 \mathrm{x}^{2.4922}$, where the form of the equation formed is a power pattern (Figure 7). With the following explanation, $y$ is the volume of the tree in cubic meters $\left(\mathrm{m}^{3}\right)$ and $\mathrm{x}$ is the 
individual diameter. The coefficient of determination formed is 0.9407 , which correlates closely to 1 (Ishihara et al. 2016), so this equation can be used to calculate the volume of standing trees in the forest. The diameter at breast height $(\mathrm{DBH})$ can predict the volume of timber in the tropical forest (Harja et al. 2012; Tang et al. 2017; Andrade et al. 2019).

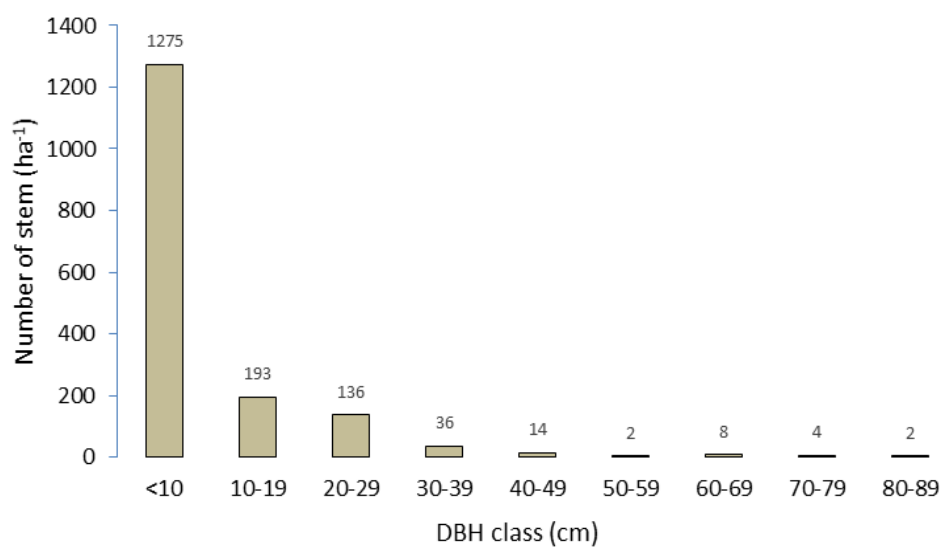

Figure 3. Distribution of the number of individuals in units of area (hectares) by diameter class in the Murkim and Teiraplu Sub-district

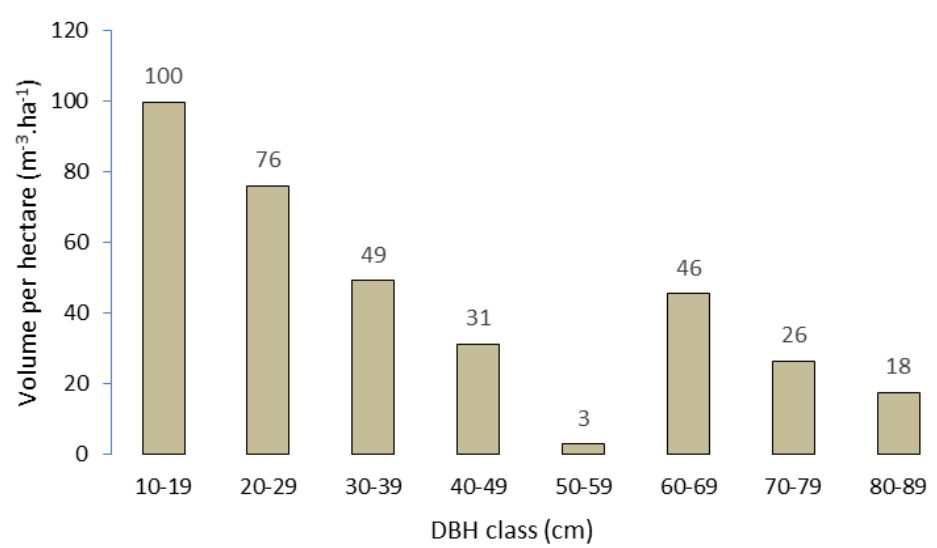

Figure 4. Potential standing wood volume in units of area (hectare) based on the distribution of diameter classes in the Murkim and Teiraplu Sub-district

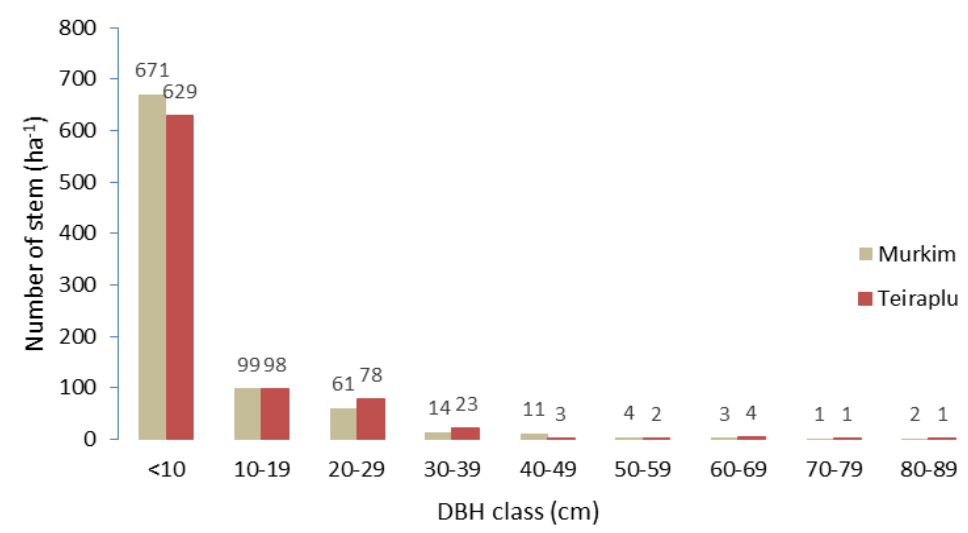

Figure 5. Distribution of the number of individuals in units of area (hectares) by diameter class in Murkim and Teiraplu Sub-district 


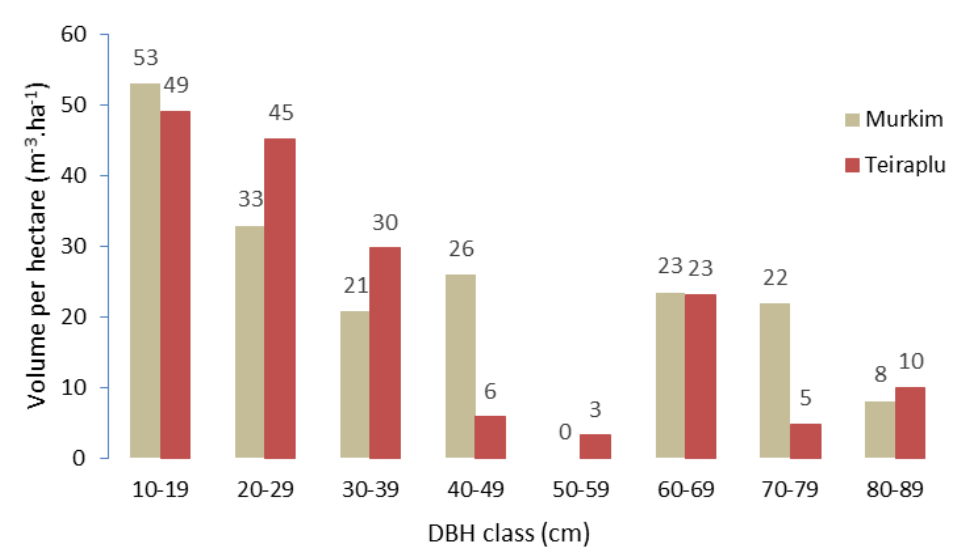

Figure 6. Distribution of potential standing timber volume in units of area (hectares) based on diameter classes in Murkim and Teiraplu Sub-district

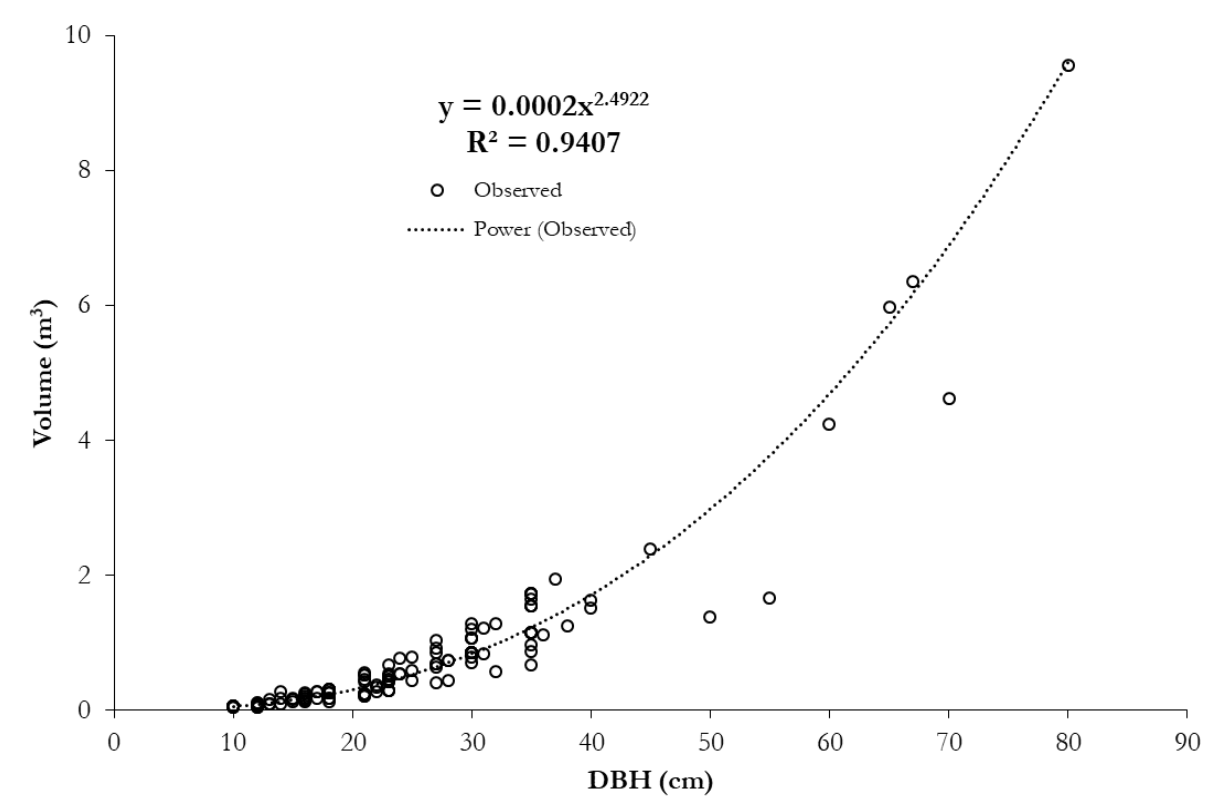

Figure 7. The relationship between the diameter $(\mathrm{DBH})$ in $\mathrm{cm}$ and the volume of standing wood in cubic meters $\left(\mathrm{m}^{3}\right)$. Information: $\mathrm{y}=$ $0.0002 \mathrm{x}^{2.4922}$ is an equation formed with the coefficient of determination $\left(\mathrm{R}^{2}\right)$ is 0.9407 . In this equation, $\mathrm{x}$ is the diameter $(\mathrm{DBH})$ in $\mathrm{cm}$ and $y$ is the volume of wood standing in cubic meters $\left(\mathrm{m}^{3}\right)$

\section{Tree diversity to support sustainable product}

The tropical rainforest provides high diversity of vegetation in which the trees are the dominant structure and other lifeforms (Murdjoko et al. 2021a; Murdjoko et al. 2021b). This area is part of a lowland area comprising the ecological process without human intervention. The regeneration of trees depends on the existence of putative parent trees. Besides, seed dispersal also plays a crucial role in the resurrection and distribution of species. This research revealed that the forest is a stably ecological circumstance where vertical layers such as forest floor and canopy are naturally delicate (Murdjoko et al. 2017; Moreno-Mateos et al. 2020). Therefore, the stock of small trees as future trees are available in this forest regardless of the particular species. Then, the forest would grow naturally as the character of old-growth forest (Murdjoko 2013; Murdjoko et al. 2016b). This forest also benefits other biotic factors to promote the sustainability of tropical rain forest.

As described in this research, the vertical structure of this forest uncovered that trees, particularly more giant trees, are firmly present as part of vegetation diversity. As one of the lifeforms in tropical forests, the trees contain more or less $30 \%$ of species richness, especially in the New Guinea ecosystem (Cámara-Leret and Dennehy 2019; Cámara-Leret et al. 2020). Based on the observation, local people still conduct the swidden practices as their livelihood enormously counts on the forest (Ungirwalu et al. 2014; Ungirwalu et al. 2017). As regional development, the demand for timber would probably increase to meet the infrastructure development including this area part of Pegunungan Bintang District. Thus, this finding described the timber stock and the sustainability for managing the timber product. The forest can be the source of timber 
supply, but the management must pay attention to the silvicultural method in tropical mixed forests. The selective cutting could be carried out with a certain diameter limit and logging intensity. The mechanism of timber exploitation must be in line with the national regulation.

This recommendation could be performed correctly as the local government pays attention to the regulation, socio-culture, private sector, non-governmental organizations (NGOs), and other stakeholders. To achieve the goals of sustainable forest management, actors must get involved either direct way or an indirect way. The production forests in tropical countries are mainly located close or overlaid position with areas of local people. Thus, the involvement of customary forests could be considered carefully as one of the main objectives of forest management. In this case, the timber could be the main product of the forest, but the local people must be included in this program to support regional development goals (Ungirwalu et al. 2021).

To sum up, the forest in Pegunungan Bintang Forest was formed by the high diversity of tree species known as a tropical mixed forest. The families of Moraceae, Myrtaceae, Euphorbiaceae, Lauraceae, and Anacardiaceae were the dominant families in Pegunungan Bintang Forest with a variety of species in seedlings, saplings, poles, and trees. The potency of timber can be seen from the distribution of individuals following the reverse J-shaped curve, indicating that the trees were merchantable and provided enough regeneration of trees. However, the management of timber utilization requires silvicultural treatments by applying selective logging with diameter limit cut and logging cycle to promote sustainable forest management.

\section{ACKNOWLEDGEMENTS}

We thank Pegunungan Bintang District for financial support during data collection, Papua Province for permit, Faculty of Forestry, Papua University, and we are also grateful to anonymous reviewers for improving the manuscript.

\section{REFERENCES}

Andrade VHF, Machado SDA, Figueiredo Filho A, Botosso PC, Miranda BP, Schöngart J. 2019. Growth models for two commercial tree species in upland forests of the Southern Brazilian Amazon. For Ecol Manag 438: 215-223. DOI: 10.1016/j.foreco.2019.02.030.

Cámara-Leret R, Frodin DG, Adema F, Anderson C, Appelhans MS, Argent G, Guerrero SA, Ashton P, Baker WJ, Barfod AS, Barrington D, Borosova R, Bramley GLC, Briggs M, Buerki S, Cahen D, Callmander MW, Cheek M, Chen C-W, Conn BJ, Coode MJE, Darbyshire I, Dawson S, Dransfield J, Drinkell C, Duyfjes B, Ebihara A, Ezedin Z, Fu L-F, Gideon O, Girmansyah D, Govaerts R, FortuneHopkins H, Hassemer G, Hay A, Heatubun CD, Hind DJN, Hoch P, Homot P, Hovenkamp P, Hughes M, Jebb M, Jennings L, Jimbo T, Kessler M, Kiew R, Knapp S, Lamei P, Lehnert M, P. Lewis G, Linder HP, Lindsay S, Low YW, Lucas E, Mancera JP, Monro AK, Moore A, Middleton DJ, Nagamasu H, Newman MF, Lughadha EN, Melo PHA, Ohlsen DJ, Pannell CM, Parris B, Pearce L, Penneys DS, Perrie LR, Petoe P, Poulsen AD, Prance GT, Quakenbush JP, Raes N, Rodda M, Rogers ZS, Schuiteman A, Schwartsburd P, Scotland RW,
Simmons MP, Simpson DA, Stevens P, Sundue M, Testo W, TriasBlasi A, Turner I, Utteridge T, Walsingham L, Webber BL, Wei R, Weiblen GD, Weigend M, Weston P, Wilde W de, Wilkie P, WilmotDear CM, Wilson HP, Wood JRI, Zhang L-B, Welzen PC van. 2020. New Guinea has the world's richest island. Nature 584: 579-583. DOI: 10.1038/s41586-020-2549-5.

Cámara-Leret R, Dennehy Z. 2019. Indigenous knowledge of New Guinea's useful plants: A review. Econ Bot 73: 405-415. DOI: 10.1007/s12231-019-09464-1.

Cottam G, Curtis JT. 1956. The use of distance measures in phytosociological sampling. Ecology 37: 451-460. DOI: $10.2307 / 1930167$.

de Avila AL, Schwartz G, Ruschel AR, Lopes J do C, Silva JNM, Carvalho JOP de, Dormann CF, Mazzei L, Soares MHM, Bauhus J. 2017. Recruitment, growth and recovery of commercial tree species over 30 years following logging and thinning in a tropical rain forest. For Ecol Manag 385: 225-235. DOI: 10.1016/j.foreco.2016.11.039.

Fatem SM, Djitmau DA, Ungirwalu A, Wanma OA, Simbiak VI, Benu NMH, Tambing J, Murdjoko A. 2020. Species diversity, composition, and heterospecific associations of trees in three altitudinal gradients in Bird's Head Peninsula, Papua, Indonesia. Biodiversitas 21: 35963605. DOI: 10.13057/biodiv/d210824.

Fredericksen TS, Putz FE. 2003. Silvicultural intensification for tropical forest conservation. Biodivers Conserv 12: 1445-1453. DOI: 10.1023/A:1023673625940.

Groenendijk P, Bongers F, Zuidema PA. 2017. Using tree-ring data to improve timber-yield projections for African wet tropical forest tree species. For Ecol Manag 400: 396-407. DOI: 10.1016/j.foreco.2017.05.054.

Harja D, Vincent G, Mulia R, van Noordwijk M. 2012. Tree shape plasticity in relation to crown exposure. Trees-Struct Funct 26: 12751285. DOI: 10.1007/s00468-012-0703-x.

Ishihara MI, Konno Y, Umeki K, Ohno Y, Kikuzawa K. 2016. A new model for size-dependent tree growth in forests. PLoS One 11: 1-18. DOI: 10.1371/journal.pone.0152219.

Kartikasari SN, Marshall AJ, Beehler B. 2012. Ekologi Papua. Yayasan Pustaka Obor, Yogyakarta. [Indonesian]

Kübler D, Hildebrandt P, Günter S, Stimm B, Weber M, Muñoz J, Cabrera O, Zeilinger J, Silva B, Mosandl R. 2020. Effects of silvicultural treatments and topography on individual tree growth in a tropical mountain forest in Ecuador. For Ecol Manag 457: 1-9. DOI: 10.1016/j.foreco.2019.117726.

Kuswandi R, Murdjoko A. 2015. Population structures of four tree species in loggpopulation structures of four tree species in logged-over tropical forest in South Papua, Indonesia: An integral projection model approach. Indones $\mathbf{J}$ For Res 2: 93-101. DOI: 10.20886/ijfr.2015.2.2.93-101.

Lohbeck M, Poorter L, Martínez-Ramos M, Rodriguez-Velázquez J, van Breugel M, Bongers F. 2014. Changing drivers of species dominance during tropical forest succession. Func Ecol 28: 1052-1058. DOI: 10.1111/1365-2435.12240.

Mahayani NPD, Slik FJW, Savini T, Webb EL, Gale GA. 2020. Rapid recovery of phylogenetic diversity, community structure and composition of Bornean tropical forest a decade after logging and post-logging silvicultural interventions. For Ecol Manag 476: 1-12. DOI: $10.1016 /$ j.foreco.2020.118467.

Margono BA, Potapov PV, Turubanova S, Stolle F, Hansen MC. 2014. Primary forest cover loss in indonesia over 2000-2012. Nat Clim Change 4: 730-735. DOI: 10.1038/nclimate2277.

Menezes GSC, Cazetta E, Dodonov P. 2019. Vegetation structure across fire edges in a Neotropical rain forest. For Ecol Manag 453: 1-11. DOI: 10.1016/j.foreco.2019.117587.

Moreno-Mateos D, Alberdi A, Morriën E, van der Putten WH, RodríguezUña A, Montoya D. 2020. The long-term restoration of ecosystem complexity. Nat Ecol Evol 4: 676-685. DOI: 10.1038/s41559-0201154-1.

Murdjoko A. 2013. Recuperation of non-commercial trees in logged forest in Southern Papua, Indonesia. J Manajemen Hutan Tropika 19: 94102. DOI: $10.7226 /$ jmht.19.2.94.

Murdjoko A, Djitmau DA, Ungirwalu A, Sinery AS, Herlina R, Siburian S, Mardiyadi Z, Wanma AO, Wanma JF, Rumatora A, Mofu WY, Worabai D, May NL, Jitmau MM, Alexander G, Mentansan F, Krey K, Musaad I, Manaf M, Abdullah Y, Mamboai H, Pamuji KE, Raharjo S, Kilmaskossu A, Bachri S, Mikael N, Benu H, Tambing J, Kuswandi R. 2021a. Pattern of tree diversity in lowland tropical forest 
in Nikiwar, West Papua, Indonesia. Dendrobiology 85: 78-91. DOI: 10.12657/denbio.085.008.

Murdjoko A, Jitmau MM, Djitmau DA, Mardiyadi Z, Rumatora A, Mofu WY, Sineri AS, Fatem SM, Worabai D, May NL, Tokede MJ, Warmetan H, Wanggai CB, Wanma JF, Sirami EV, Paembonan JB, Unenor E, Kuswandi R, Lekitoo K, Khayati L, Benu NMH, Tambing J, Saragih ABS. 2020. Heterospecific and conspecific associations of trees in lowland tropical forest of New Guinea. Biodiversitas 21: 4405-4418. DOI: 10.13057/biodiv/d210960.

Murdjoko A, Marsono D, Sadono R, Hadisusanto S. 2016a. Plant species composition and their conspecific association in Natural Tropical Rainforest, South Papua. Biosaintifika 8: 33-46. DOI: 10.15294/biosaintifika.v8i1.5217.

Murdjoko A, Marsono D, Sadono R, Hadisusanto S. 2016b. Population dynamics of pometia for the period of post-selective logging in Tropical Rainforest, Southern Papua, Indonesia. Biosaintifika 8: 321330. DOI: 10.15294/biosaintifika.v8i3.6309.

Murdjoko A, Marsono D, Sadono R, Hadisusanto S. 2016c. Tree association with pometia and its structure in logging concession of South Papua Forest. J Trop For Manag 22: 180-191. DOI: 10.7226/jtfm.22.3.180.

Murdjoko A, Marsono D, Sadono R, Hadisusanto S. 2017. Recovery of residual forest ecosystem as an impact of selective logging in South Papua: An ecological approach. Biotropia 24: 230-245. DOI: 10.11598/btb.2017.24.3.732.

Murdjoko A, Ungirwalu A, Mardiyadi Z, Tokede MJ, Djitmau DA, Benu NMH. 2021b. Floristic Composition of buah hitam habitats in lowland tropical mixed forest of West Papua, Indonesia. Floresta e Ambiente 28: 1-13. DOI: 10.1590/2179-8087-FLORAM-2021-0042.

Myanmar I. 2016. Assessment of the recovery of a secondary tropical dry forest after human disturbance in Central Myanmar. J Trop For Sci 28: $479-489$

Padmakumar B, Sreekanth NP, Shanthiprabha V, Paul J, Sreedharan K, Augustine T, Jayasooryan KK, Rameshan M, Mohan M, Ramasamy EV, Thomas AP. 2018. Tree biomass and carbon density estimation in the tropical dry forest of southern western Ghats, India. IForest 11: 534-541. DOI: 10.3832/ifor2190-011.

Rozendaal DMA, Bongers F, Aide TM, Alvarez-Dávila E, Ascarrunz N, Balvanera P, Becknell JM, Bentos TV, Brancalion PHS, Cabral GAL, Calvo-Rodriguez S, Chave J, César RG, Chazdon RL, Condit R, Dallinga JS, De Almeida-Cortez JS, De Jong B, De Oliveira A, Denslow JS, Dent DH, DeWalt SJ, Dupuy JM, Durán SM, Dutrieux LP, Espírito-Santo MM, Fandino MC, Fernandes GW, Finegan B, García H, Gonzalez N, Moser VG, Hall JS, Hernández-Stefanoni JL, Hubbell S, Jakovac CC, Hernández AJ, Junqueira AB, Kennard D, Larpin D, Letcher SG, Licona JC, Lebrija-Trejos E, Marín-Spiotta E, Martínez-Ramos M, Massoca PES, Meave JA, Mesquita RCG, Mora F, Müller SC, Muñoz R, De Oliveira Neto SN, Norden N, Nunes YRF, Ochoa-Gaona S, Ortiz-Malavassi E, Ostertag R, Peña-Claros M, Pérez-García EA, Piotto D, Powers JS, Aguilar-Cano J, Rodriguez-Buritica S, Rodríguez-Velázquez J, Romero-Romero MA,
Ruíz J, Sanchez-Azofeifa A, De Almeida AS, Silver WL, Schwartz NB, Thomas WW, Toledo M, Uriarte M, De Sá Sampaio EV, Van Breugel M, Van Der Wal H, Martins SV, Veloso MDM, Vester HFM, Vicentini A, Vieira ICG, Villa P, Williamson GB, Zanini KJ, Zimmerman J, Poorter L. 2019. Biodiversity recovery of neotropical secondary forests. Sci Adv 5: 1-10. DOI: 10.1126/sciadv.aau3114.

Sonbait LY, Manik H, Warmetan H, Lina Y, Wambrauw D, Sagrim M, Djitmau DA, Wanggai J, Rettob BB, Murdjoko A. 2021. The natural resource management to support tourism: A traditional knowledge approach in Pegunungan Arfak Nature Reserve, West Papua, Indonesia. Biodiversitas 22: 4466-4474. DOI: $10.13057 / \mathrm{biodiv} / \mathrm{d} 221040$.

Spellerberg IF, Fedor PJ. 2003. A tribute to Claude-Shannon (1916-2001) and a plea for more rigorous use of species richness, species diversity and the 'Shannon-Wiener' Index. Glob Ecol Biogeogr 12: 177-179. DOI: 10.1046/j.1466-822X.2003.00015.x.

Tang C, Wang CS, Pang SJ, Zhao ZG, Guo JJ, Lei YC, Zeng J. 2017. Stem taper equations for Betula alnoides in South China. J Trop For Sci 29: 80-92

Tawer P, Maturbongs R, Murdjoko A, Jitmau M, Djitmau D, Siburian R, Ungirwalu A, Wanma A, Mardiyadi Z, Wanma J, Rumatora A, Mofu W, Sinery A, Fatem S, Benu N, Kuswandi R, Lekitoo K, Khayati L, Tambing J. 2021. Vegetation dynamic post-disturbance in tropical rain forest of Bird's Head Peninsula of West Papua, Indonesia. Ann Silvic Res 46: 48-58. DOI: 10.12899/ASR-2145.

Ungirwalu A, Awang SA, Murdjoko A. 2014. Model aplikasi agroforestri tumbuhan buah hitam (Haplolobus monticola Husson) berbasis pengetahuan lokal etnis Wandamen-Papua. In: Prehaten D, Syahbudin A, Andiyani RD (eds.). Prospek Pengembangan Perhutanan Sosial di Papua; Prosiding Seminar Nasional Silvikultur II : Pembaharuan Silvikultur untuk Mendukung Pemulihan Fungsi Hutan Menuju Ekonomi Hijau. Universitas Gadjah Mada, Yogyakarta, 28 Agustus 2014. [Indonesian]

Uddin M, Chowdhury FI, Hossain MK. 2020. Assessment of tree species diversity, composition and structure of Medha Kachhapia National Park, Cox's Bazar, Bangladesh.Asian J For 4: 15-21. DOI: 10.13057/asianjfor/r040104.

Ungirwalu A, Awang SA, Runtuboi YY, Peday MY, Marwa J, Maitar B, Murdjoko A, Fatem SM. 2021. Customary forests in West Papua: Contestation of desires or needs? For Soc 5: 365-375. DOI: $10.24259 /$ fs.v5i2.13350

Ungirwalu A, Awang SA, Suryanto P, Maryudi A. 2017. The ethnotechno-conservation approach in the utilization of black fruit (Haplolobus sp.) by the Wandamen Ethnic of Papua, Indonesia. Biodiversitas 18: 1336-1343. DOI: 10.13057/biodiv/d180408.

Whitfeld TJS, Lasky JR, Damas K, Sosanika G, Molem K, Montgomery RA. 2014. Species richness, forest structure, and functional diversity during succession in the New Guinea Lowlands. Biotropica 46: 538548. DOI: 10.1111/btp.12136. 